\title{
Celebrating Benedict Kiely 2007 Benedict Kiely Weekend Keynote Address
}

\author{
David Pierce \\ York, UK
}

Copyright (c) 2008 by David Pierce. This text may be archived and redistributed both in electronic form and in hard copy, provided that the author and journal are properly cited and no fee is charged for access.

\begin{abstract}
Benedict Kiely (1919-2007) has an annual weekend devoted to his memory as one of Ireland's leading writers in the modern period. The sixth such event was held in the newly-built Strule Arts Centre in Omagh in September 2007. Kiely lived most of his life in Dublin, pursuing a career as a journalist and a writer, but his roots were in County Tyrone. Educated by the Christian Brothers in Omagh, he embarked on a Jesuit novitiate in the Irish Midlands but this was cut short by a spinal injury, which meant a year of confinement on the broad of his back. Subsequently, he went on to read English and History at University College Dublin. His journalistic career took him first to the Irish Independent and then to the Irish Press, where he was literary editor. In the 1960s he took up visiting professorships at several North American colleges in Oregon and Tennessee. On his return he became well-known on Irish radio for talks and discussion programmes, and he was a regular contributor to Sunday Miscellany. A sharp observer of the Northern scene, he was particularly disturbed by the upsurge in violence in the recent Troubles, airing his grievances in imaginative works such as Proxopera (1977) and Nothing Happens in Carmincross (1985). He died in Dublin on 9 February 2007 after a short illness, and after Requiem mass in Donnybrook he was laid to rest in the Dublin Road Cemetery in Omagh. The following is the text of the opening address I was invited to give at the sixth annual weekend. I spoke about Kiely's sense of connection running through his writings.
\end{abstract}

Key Words. Benedict Kiely, traditional music, rivers and the natural world, the North of Ireland, the oral tradition of storytelling, recitation, Robbie Burns, the sympathetic imagination, the Troubles.

Resumen. Benedict Kiely (1919-2007), uno de los principales escritores de Irlanda de la época moderna, cuenta con un fin de semana anual dedicado a su memoria. La sexta convocatoria se celebró en el recién construido Centro Strule Arts de Omagh en septiembre del 2007. Kiely vivió la mayor parte de su vida en Dublín, donde desarrolló la actividad de periodista y escritor, pero sus raíces estaban en el Condado de Tyrone. Educado por los Hermanos de la Doctrina Cristiana en Omagh, emprendió un noviciado con los jesuitas en la región central irlandesa, que abandonaría al sufrir una lesión de la columna vertebral que le mantuvo confinado en cama durante un año. Posteriormente, se licenció en Inglés e Historia en University College Dublin. Su carrera periodística le llevó inicialmente al Irish Independent y luego al Irish Press, del que fue redactor literario. En los años 60 enseñó como profesor invitado en varias universidades norteamericanas en Oregon y Tennessee. A su regreso alcanzó popularidad en la radio con charlas y programas de debate, así como con sus contribuciones para el Sunday Miscellany. Observador agudo de la escena norirlandesa, se sintió particularmente afectado por el estallido de la violencia en el reciente conflicto, y manifestó su malestar en obras de carácter imaginativo tales como Proxopera (1977) y Nothing Happens in Carmincross (1985). Murió en Dublín el 9 de febrero del 2007 tras una breve enfermedad, y después de una breve misa de Requiem en Donnybrook sus restos fueron enterrados en el Dublin Road Cemetery de Omagh. Lo que sigue es el texto de la conferencia inaugural que fui invitado a pronunciar para la sexta convocatoria anual. Hablé del sentimiento de conexión que se percibe en toda la obra de Kiely.

Palabras Clave. Benedict Kiely, música tradicional music, ríos y naturaleza, el Norte de Irlanda, la tradición oral, recitar, Robbie Burns, la imaginación comprensiva, el conflicto norirlandés. 
It's a great pleasure to be here in Omagh for the Benedict Kiely Weekend. It's also a great honour and a privilege to give this opening keynote address and to welcome you all to the first Benedict Kiely weekend to be held since his death in February this year. In the presence of his widow Frances and members of his family, it promises to be a memorable weekend with an appropriate mixture of serious reflection, serious enjoyment, and serious entertainment. The programme includes talks by Eileen Battersby, literary editor of the Irish Times, and by the playwright and musician Gerry Lynch, with readings by the author and critic Patricia Craig, by Michael Longley, recently appointed Professor of Poetry for Ireland, by the novelist and playwright Lucy Caldwell, and by the poet Francis Harvey, as well as music by Liam Moore, Ray Moore, and Mairead Kelly.

It couldn't but be a memorable occasion especially as our weekend here at the new Strule Arts Centre occupies a site between Sharon Shannon, the lively accordion player, who I see was on the programme at Dun Uladh last weekend, and Nuts about Squirrels, which I believe is the topic for the last weekend in September at Gortin Forest Park. Our weekend is slightly more high-brow being a literary event with poetry readings and creative writing workshops, but for all that we shouldn't get carried away. After all, Ben Kiely was a writer who was himself positioned somewhere between traditional Irish music and a natural world teeming with life and interest, a writer who possessed a keen ear for the language and a keen eye for the world around him. Or if we were to extend the imagery slightly, we might say of Kiely that he was a forager like the squirrel and a celebrator like the traditional musician.

Positioned thus on this year's September programme for west Tyrone would surely have amused him. Music and the natural world. Benedict Kiely between music and squirrels. He would then have been tempted to give it a slight twist to activate that sophisticated punctuation mark in English, the colon, which he often used in a rhetorical as opposed to a strictly grammatical sense. 'Music and squirrels: the fiction of Benedict Kiely.' That would have tickled him and set him off on another story, a memory from childhood, or from his schooldays in 'sweet Omagh Town' or exploring the countryside around these parts, the streams and rivers and interlocking hills, the country cottages, the Big House, the estates emptied of wood and men by the Great War, the flax-dams and the clothes worn by the fashionable in the great cities of the world. Or he might have recalled an incident from the last of the hiring fairs in the 1930s, or a snatch from a nationalist song or something to do with the 'counties of contention', the title of one of his early polemical books. Start with the streets of Omagh or Red Squirrel Week and you end up with the world or, better still for there was nothing provincial or politically correct about Kiely, start with the one of the wettest towns in provincial Ireland and end up in the American mid-west with the Beauty Queen of Iowa, the title of one of his delightful non-pc stories.

I never had an opportunity of meeting the 'gentle poet' in person but I feel I know him through his writings and through his talks on RTE radio. 'The most urbane voice on Irish radio in the twentieth century' is how I describe him in Light, Freedom and Song (2005), my cultural history of modern Irish writing. I suspect he would have enjoyed this moment listening in to someone from across the water singing his praises amid the surroundings of his home town in an accent that is neither Scottish nor Irish but, when it's not RP, southern English. He was of course a 'gregarious' writer, if I can use that term in a positive sense and not in the sense that we find it in his novel The Captain with the Whiskers (1960) (where it's employed to discourage special friendships). A journalist cannot but be gregarious, but Kiely's gregariousness was so special that in time he came to know everyone in Ireland, north and south of the border and across at least three generations - Brinsley MacNamara, Patrick Kavanagh, Brendan Behan, John Montague, Brian Friel, Seamus Heaney to name but a few. He clearly cultivated friendships, not only here in Ireland but among his American acquaintances. At the same time, he would have appreciated my status as an interested spectator, for he understood the way of the world, how it never quite conforms to the expected, and I thank the organisers for inviting me to participate in this celebration. And just in case you think my accent confirms my status as an outsider, perhaps I should add that I took my first steps in Ireland in my grandmother's thatched cottage in the summer of 1948, that I attended an American Wake in the mid-fifties in a 
house now owned by the uillean piper Davy Spillane, and that my Irish family hosted some of the last house dances in the west of Ireland where an unknown Micho Russell would play all night amid the crush of the set dancers and the uneven flagstones, all of which I write more about in Reading Joyce (2008). Everything, including loss and all sorts of odd memories, comes along with us from the past.

The byways, lanes and boreens, the ancient footpaths, the minor roads, the streams and rivers - this is Kiely's chosen world. His father 'chained' Ireland, that is, he worked for the Ordnance Survey and used chains to measure the country. Ben, his youngest son, engaged in a different sort of mapping or chaining. Get off the trunk roads and motorways, and life isn't so clear-cut or chiselled out or indeed measured. As he often reminds us in the course of his writings, the rivers Camowen and the Drumragh meet in Omagh and they then become the Strule. The Strule in turn runs north into the Fairywater and emerges as the graceful Foyle. 'Down then by Derry' as he calls his story where he writes about this. What's in a name? Rivers of connection would have been his certain response. Not just a name therefore. In the last memoir he wrote, The Waves Behind Us (1999), as if he can't let go, he rehearses again the course of these everflowing, sparkling rivers, now behind him.

'Howandever' to quote the man himself, since we're got off on beginnings and beginnings in general, if we were to leave on one side for a moment his biographical details and family history and attachment to home, we might want to reflect on the common ground Kiely shares with other Irish writers. In the book on Joyce I've just finished writing, this is what I have to say in passing about rituals and the imagination of the modern Irish writer:

If you're asked as a writer to draw water from the well of Irish life, you'll find like Joyce that what you return with again and again is ritual. Yeats begins with the ritual of storytelling in The Celtic Twilight (1893), Synge with the ritual of weddings and wakes in his plays, Roddy Doyle with the ritual of abuse, John McGahern with the ritual connected with the seasons. Rituals give us a culture, and, in Ireland particularly, culture, whether urban or rural, gives us rituals.
The observation comes in a chapter on Joyce's story 'The Sisters', and I continue by writing about attending funerals and wakes in the west of Ireland and how the term 'faithful departed' stamps itself on the living as much as the dead.

What Benedict Kiely returns with from the well of Irish life is not only a filial attention to those who went before him but also an interest in the allied rituals of recitation and storytelling. Few modern writers are so given to recitation, and this has nothing to do with signs of a misspent youth poring over Irish Fireside Songs or Our Boys, the Christian Brothers' magazine, or with parading his knowledge or with showing off to a roomful of academics or indeed with betraying his postmodern credentials. You might remember the charge made against Brother MacKenna in his semi-autographical novel There Was an Ancient House (1955), how he 'talks too much about books'. Yes, literature was a temptation for Benedict Kiely, who at one time thought he might become a Jesuit priest. Fortunately for us, it was a temptation he couldn't resist. Indeed, although he found his work banned by the Irish Censorship Board, he went on to devote his whole life to talking about books, and what emerged was something unique. For his fiction reaches all the time into the rich storehouse of European literature and Irish balladry. Proust, Burns and Shakespeare rub shoulders with Paddy Tunney, the traditional singer from these parts, and with ballads such as your own 'Sweet Omagh Town' or 'The Hills Above Drumquin'. It would be somewhat nerdish to count all the quotations from other writers or Irish songs, but if you did I bet it would exceed your expectations.

Keeping up is what his reader is often required to do, but it's supplemented by something else in Kiely. If you come across a sentence that contains the phrase 'with my dog and gun though the blooming heather' - and more often than not he sets out the lines not as verse but as prose, as if he wants to emphasise the theme of continuity - before you realise it, if you've been brought up properly, you're singing the song 'The Mountain Streams' to yourself:

To seek for pastime I took my way, Where I espied a lovely fair one, Her charms invited me a while to stay. 
You're there with him, Benedict Kiely, not the provincial writer, as he might be seen by some, but the surviving countryman, the 'wordweaver' heading back up to the 'mountain streams where the moorcocks crow'. In this sense, recitation gives us not an empty classroom ritual but a living culture, a culture which still has the potential to snap into place when called upon.

Kiely is also quite capable of doubling back on himself and giving us the comic side of his inbred facility to recite. I'm thinking of that moment in his much-admired story 'The Night We Rode with Sarsfield', a story I reproduce in my Cork Reader (2001), when the young boy, before he internalised anything about the politics of Orange and Green, recites in the house of a Presbyterian neighbour the poem celebrating the rearguard action of the Jacobite leader Patrick Sarsfield at the Siege of Limerick in 1690. His wised-up older sisters 'never recovered from the shock'. It should have been a moment of triumph for the boy, how he repeated word-perfect the six-stanza 48-line ballad, which for his sisters offered a way of blotting out his efforts at singing a rebel song about being off to Dublin in the green. But that wouldn't have produced a story. On the other hand, how could the boy be so innocent as to imagine riding with General Sarsfield in the house of 'a good Orangeman' with the $12^{\text {th }}$ July coming on and the sash hanging up to air 'for the great Walk and the great Day' as Kiely recalls in his book of songs and places And As I Rode by Granard Moat (1996)? How could he, especially as the Presbyterian couple, a brother and sister, had been kind enough to share with his family the roof of their house in the violent years following the Great War and the birth of the Free State? The question is rhetorical: I'm not seeking an answer. What Kiely evokes for us is a reminder of a different age in both senses of the term, for what he is recalling is an engaging moment from his childhood in the $1920 \mathrm{~s}$, a moment much appreciated at the time by the graceful Orangeman Willy Norris.

Thank God, we might say, for the occasional party pieces that go wrong, for what they betray is not only the neighbourliness that once existed between neighbours across the sectarian divide but also the sense of ritual perceived now not as a clash of cultures but as an encounter between different traditions, one in the shadow of the other. Is the story about longing or belonging? Longing for a past where people mixed more? Mixing, incidentally, was important to Kiely. Omagh was a garrison town but its soldiers mixed in with the locals, unlike in the time of the recent Troubles when that proved impossible. Or is the big-eyed Kiely telling us something about the nature of tribal identity and how belonging comes into play in a divided society? Playing gooseberry, if we were to hover over the opening image to that story, is an awkward reminder of being on the outside of things, of not belonging. The story also reminds us we should be grateful for the boy who grew up without any sense of priggishness or superiority, able to recall such an embarrassing moment in one sense without embarrassment and to approach the whole scene through humour and not satire. Rituals, as I say, give us a culture, and the gentle Kiely was a writer who knew how to offend when he needed to, but, more importantly to my mind, he also knew how never to offend gratuitously.

As for the ritual of storytelling, we might well agree that Kiely is one of modern Ireland's leading storytellers, ever alert to the wrinkled effects of time and the dark secrets of the heart. In the long winter evenings before the coming of electricity, what was there to do years ago but listen to music, get on each other's nerves, and tell stories? Irish Fireside Tales or Beside the Fire are favourite kinds of title for collections of Irish stories in the nineteenth century, the setting being in harmony as it were with the subject-matter and disposition of the stories themselves. Such stories told in hillside cottages might have been garnered from the ancient repertoire of myths concerning Oisin and Finn, or Diarmuid and Grainne, or Cuchulain of Muirthemne. Or they might have been traditional tales about the fairies or fields or wells, or more salacious stories such as we read about in Eric Cross's 1942 collection The Tailor and the Ansty. Not surprisingly, as we learn in one of his most impressive stories, 'Homes on the Mountain', the Kiely family possessed a whole series of pamphlets entitled 'Irish Fireside Songs'.

Kiely taps into this hillside culture of storytelling, 'the heroes in the dark house' as one of his stories is called, and he reminds us of its continuing power. In the 1970s the County Kerry shanachie or storyteller Eamon Kelly could hold a radio audience for twenty minutes and more with stories about the Gobán Saor, that mythical mason and builder of 
mountains and round towers. 'It is a long time since the Goban Saor was alive,' so begins one of the stories about the Goban Saor in Patrick Kennedy's Legendary Fictions of the Irish Celts (1866). 'That was the house where I put the gooseberries back on the bushes by sticking them on the thorns,' so begins 'The Night We Rode with Sarsfield'. Kiely is a traditional teller of tales, except the stories he tells betray a certain angularity and exhibit a more modern appeal. In this regard, his 'Tam O'Shanter' Burns story, 'A Great God's Angel Standing', is a remarkably engaging and racy inquiry into the age-old conflict between the body and the soul told through the eyes of a Catholic priest called Father Paul and a local rake called Pascal. There is something riveting about the whole story, not least when the celibate priest (who once was tempted away from his calling) quotes Burns to his womanising friend 'Pleasures are like poppies spread'. In Kiely's hands, we are constantly reminded of a leisurely tradition that's been brought up-todate, conscious of its past and indebted in no small measure to an unsentimental take on the world. A patient tradition that knows how to wait.

In passing, I suspect it's because he's steeped in this cross-over tradition, that deep space between an oral and a literary tradition, that there are few soft centres in his short stories. That was the accusation we might recall made by Francis Stuart against Frank O'Connor (the remark is reproduced in my Cork Reader on page 831). As you try and connect replacing gooseberries at the beginning of the story we're been discussing and the boy's gaff at reciting a ballad about Sarsfield in a house whose owner is named after William of Orange, there's no place for sentimentality or symbolic cohesion. After all, 'plucked fruit is plucked forever', as he notices in the story. Once said some things can't be unsaid. Pleasures are indeed like poppies spread: 'You seize the flow'r, its bloom is shed.'

Every writer has an essential story to tell. Uncovering such an underlying story shouldn't be easy to track down in Kiely's case, for remember, we have four collections of short stories numbering over seven-hundred pages, ten novels, a monograph on William Carleton, a critical study of Irish fiction, three books which travel round the island of Ireland, a collection of Irish short stories for Penguin, a book on his adopted city Dublin and another on Yeats's Ireland, and not forgetting a children's book The Trout in the Turnhole (1996). But I think we can decipher a line as we look back on that oeuvre, that body of work, and I think it is a clear line. Above all else, as I indicate in my tribute to him in the accompanying brochure, The Waves Behind Us, published by Strule Arts Centre, the story seems to me to be about connection. That is the great theme of his life and work. From his boyhood in Omagh to Dublin as an adult, from North to South and back again, from the Irish song tradition to the European literary tradition, from popular culture to the world of books, from newsprint to the experience of ordinary people, from raconteur to storyteller, Benedict Kiely was a witness to the generous spirit that never stopped seeing connections and making things happen. He was someone who knew from the start that if you work at connection you can find something important to say and not get distracted. As he says in the Sarsfield story 'This ground is littered with things', and we can't help recalling Walter Scott's description of this part of Ireland nearly two centuries ago as 'the narrow ground'. Narrow but littered and cluttered with memories, and for that reason important. It could be dismissed as just litter, something that's for the tip or wheelie-bin, but that's Kiely's point. Keep looking and very soon, as Finnegans Wake never stops reminding us, litter has the capacity to become literature.

Let me draw this opening address to a close. I know you'll want to 'drink to the bird' who used that phrase as a title to one of his memoirs. If Benedict Kiely tells us anything it is, on the one hand, that the world we carry with us needs cherishing and remembering and, on the other hand, that at the heart of our humanity beats the sympathetic imagination. Only fanaticism was alien to this poet from 'the black Northern hills' who was, as we learn from his Jesuit novel, 'unable to find a brother's fault'. 'We were misled to expect better,' as his protagonist, the old-style nationalist Mervyn, remarks in Nothing Happens in Carmincross (1985), a remark that in some respects sums up a whole history. $\mathrm{He}$ forgot nothing and when he began writing he returned to the past, to William Carleton, the great pre-Famine novelist from near-by Clogher who too brought all his past with him when he pitched up in Dublin, and to the ancient walkways of his own childhood in Omagh near where the seven streams meet. 
'Look and see, look and remember, and then you will discover what is within' - to adapt Virginia Woolf's famous remark about life and fiction; this too would be a suitable motto for Benedict Kiely. Seeing and remembering. Squirrel things away and when the occasion arises, as in what he called the 'graceless times' of the recent Troubles, use it. Like a squirrel, his writing reminds us of food to be stored against the bleakness of winter or history, a sharp reminder of the value of foraging among what's to hand or what comes naturally.

'Everything is everywhere' observes the narrator in The Captain with the Whiskers, and in a sense it was true for Kiely. 'You're not a city but you're all the world to me,' as the line in 'The Hills above Drumquin', his favourite song, has it about his locality. Wherever he travelled, all over Ireland, the four years he spent in the States, in Britain, in Europe, he found that everything is everywhere: disputes, upsets, characters, stories and story-telling, memories and odd juxtapositions, and always those inside stories. As I say he was a leisurely observer who delighted in the 'chuman' world, to quote Peter Keown as he pats the bonnet of the 'hybrid' car in 'A Journey to the Seven Streams'. Chuman, human. Nothing Happens in Carmincross, which is one the best novels of the Troubles, constitutes his most passionate plea on behalf of the human world. Not now 'everything' and 'everywhere' but 'nothing' and one of its implied qualifications, not 'everything' but 'something'. Now insert history and the passage of time and see what

happens. Not 'Nothing Happens in Carmincross' but 'Something Happened in Carmincross'. Not everything, fortunately, but something. In quiet or forgotten places, things can happen and get out of hand. But Kiely reminds us not of tragic coincidence, that the 1998 outrage took place thirteen years or so after the publication of his fierce novel (which was set in the early 1970s), nor that the outrage took place on his birthday in August, (nor that the trial of the person thought to have been responsible for the outrage collapsed in the year of his death). No, what he underlines is that the forces of history are at work all around us and that sometimes writers are more percipient than others at registering and blunting the edge of those forces. Kiely was not only percipient but outraged, and he spent a whole novel, thank God, never getting it out of his system.

It's a good place on which to end this tribute and keynote address. Suddenly that is. Without more ado. Omagh, 'the county town of Tyrone, well-built and prosperous-looking, but not a tourist-resort', as your town is described in Baddeley's 1897 Guide to Ireland. Not a tourist-resort but, as Kiely reminds us, a place to return to. In The Cards of the Gambler, written in 1953, over a half-century ago, with God and death in mind, Kiely anticipated his own return: 'Every man at the end should return to the place he started in'. In his youth, a certain religious single-mindedness appealed to a young man anxious to serve some higher goal, but he is at his best on the journey home. Enjoy the weekend. Whatever your age or background or religious persuasion or national identity, Benedict Kiely has something for everyone, by which I mean something to be enjoyed and valued. Think of that phrase 'Everything is everywhere.' Isn't that the only politics worth talking about? I'd like to hear what you think

\section{Works Cited}

Counties of Contention: A Study of the Origins and Implications of the Partition of Ireland (Cork: Mercier 1945).

Poor Scholar: A Study of the Works and Days of William Carleton 1794-1869 (London \& New York, Sheed \& Ward, 1947; Dublin, The Talbot Press, 1972);

The Cards of the Gambler (London: Methuen, 1953).

There Was an Ancient House (London: Methuen 1955).

The Captain with the Whiskers (London: Methuen 1960).

Introduction to Paddy Tunney, The Stone Fiddle: My Way to Traditional Song (Dublin: Gilbert Dalton 1979).

Nothing Happens in Carmincross (London: Victor Gollancz; Boston: David R. Godine, 1985).

God's Own Country: Selected Stories 1963-1993 (London: Minerva, 1993).

Drink to the Bird: An Omagh Boyhood (London: Methuen 1992).

The Trout in the Turnhole (Dublin: Wolfhound, 1996). 
And As I Rode by Granard Moat (Dublin: Lilliput, 1996).

The Waves Behind Us: Further Memoirs (London: Methuen, 1999).

The Collected Stories of Benedict Kiely (Introduction Colum McCann) (London: Methuen, 2003).

\section{David Pierce}

Irish Writing in the Twentieth Century: A Reader (Cork: Cork University Press, 2001).

Light, Freedom and Song: A Cultural History of Modern Irish Writing (London and New Haven: Yale University Press, 2005).

Reading Joyce (Harlow: Pearson Longman, 2008).

Other references

Patrick Kennedy. Legendary Fictions of the Irish Celts (London: Macmillan, 1866)

Eric Cross, The Tailor and the Ansty (London: Chapman and Hall, 1942).

Baddeley’s Guide to Ireland Part 1 (London: Thomas Nelson, 1897).

For more information on Benedict Kiely (incomplete), see

http://www.pgil-eirdata.org/html/pgil_datasets/authors/k/Kiely,Ben/life.htm

For images of Kiely on the net, see

http://images.google.co.uk/images? $\mathrm{q}=$ benedict + kiely\&gbv $=2 \&$ ndsp $=18 \&$ svnum $=100 \& h \mathrm{l}=\mathrm{en} \&$ start $=0 \& s a=\mathrm{N}$

For information about Strule Arts Centre, see current programme of events

http://www.omagh.gov.uk/download_files/Spring08EventsProgramme.pdf 